\title{
С.Л. Кузьмин, Нууц Түвд Орон: \\ Тусгаар Тогтнол ба Эзэгнэлийн ТYYX
}

\section{О.Батсайхан}

\section{Шүумж}

Саяхан Улаанбаатар хотноо Оросын нэрт судлаач, доктор С.Л.Кузьмины “Нууц Түвд орон: Тусгаар тогтнол ба эзэгнэлийн түүх" ном монгол хэлээрорчуулагч Б.Сандагдоржын хөрвүүлснээр хэвлэгдэн гарчээ. Эл ном анх орос хэлээр Москвад хэвлэгдсэн юм. Түвд орон эртнээс барууныхны сонирхолыг гойд татаж ирсэн бөгөөд сүүлийн жилүүдэд барууны орнуудын эрдэмтэд түвдээр амьсгалж байгаа гэвэл хэтрүүлэг болохгүй гэж бодно. Энэ нь Түвдийн өнөөгийн байдалтай холбоотой ч бас Түвдийн түүх, соёл, уламжлал, шашинтай шууд холбоотой билээ. Ингээд доктор С.Л.Кузьмины Нууц Түвд орны тухайд товч өгүүлье.

Эл номын оршлыг Монголын түүхэнд Дилов хутагт хэмээн алдаршиж, улмаар АНУ-д дүрвэн амьдарч байгаад таалал болсон хутагтын хойд дүр болох Халимагийн лам-Тэло Тулку Ринбүүчи бичжээ. Доктор С.Л.Кузьмин өөрийн биеэр Түвдэд хэд хэдэн удаа зочилж, түвд хүмүүсийн амьдрал, зан заншил, ахуйтай биечлэн танилцаж, гадаадын олон орны эх сурвалж ашиглан судалгаа хийж, Түвдийн талаар хэн хүнд бүрэн ойлголт өгөхүйц хэмжээний томоохон бүтээлийг туурвижээ. Ном нь Түвдчүүдийн газар зүй ба гарал үүсэл, Эртний ба дундад зууны үе, Чин гүрний үе, Тусгаар тогтнолын сүүлчийн жилүүд, Шашин ба соёл, Төр, нийгмийн байгуулалт, эдийн засаг, «Энх тайван чөлөөлөлт» ба түүний уршиг дагавар, Ардын бослогоос соёлын хувьсгал хүртэл, аугаа их пролетарийн соёлын хувьсгал, Маогийн үеийн үр дүн, Сэргээн босголт ба шинэчлэл, Түвдийн ард түмний тэмцэл, Далай лам ба түвдийн дүрвэгчид, Шашин, Өөртөө засах эрх ба хүн ам зүй, Хэл, боловсрол, соёл, Байгаль орчны байдал, Эдийн засаг, Цэрэгжилт, Амьдралын түвшин ба эрүүлийг хамгаалалт, Түвд орон хятадын салшгүй хэсэг мөн үү?, Олон улсын эрх зүй болон хятадын уламжлал дахь төрт ёс, Хятад ба “хятадын эзэнт улсуудын” тухай, Хятадад үндэсний асуудлыг шийдвэрлэсэн нь, Түвдийн статус: түүхэн өнгөрсөн үе , Түвд-монголын соёл иргэншил бөхөж байгаа юу? Гэсэн 12 бүлэгтэй бас олон зүйлтэй юм.

Бүлэг зүйлийн нэрнээс үзвэл хэр өргөн хүрээтэй асуудал хамарсныг харж болохоос гадна орчин үеийн Түвд орон Хятадын салшгүй хэсэг биш гэсэн дүгнэлт хийсэнийг төвөггүй харж болохоор байна. Ингэхдээ зохиогч Түвд урьд өмнө бусад улсын, тухайлбал Хятадын нэг хэсэг байгаагүй гэсэн түүхэн үндэслэлийг гаргажээ. Түвдийг БНХАУ-ын бүрэлдэхүүнд оруулсан нь хууль ёсны үйлдэл биш, Түвд бол эзлэгдсэн орон хэвээр байгаа юм хэмээн зохиогч дүгнэсэн байна.

Доктор С.Кузьмин Орос оронд Түвдийн асуудалд хэрхэн хандаж ирсэн талаар өгүүлэхдээ “Эхлээд Хятадын Коммунист Намын хийж буй ажлыг ямар ч эргэлзээгүй магтан дуулж, түүнийг эсэргүүцэгчдийн бүх үйлдлийг империализмын өдөөн хатгалга хэмээн тайлбарлаж 
байлаа. Дараа нь Н.С. Хрущевийн үед БНХАУ-тай харилцаа муудсанаас хойш шүүмжлэлийн үе эхэлсэн билээ.Маогийнхан «марксизмыг мушгин гуйвуулж» байгаад гол үндсэн анхаарал хандуулах болов.Гэхдээ зарим бүтээл түүхийн үнэт мэдээллийн эх сурвалж болсон юм.ЗСБНХУ, БНХАУ-ын харилцаа хэвийн болох үед олон ургалч үзэл бий болов.Орост Мао Зедун болон хятадын шинэчлэгчдийг бишрэн магтахаас эхлээд хүний эрх хамгаалах үзэл бодлын үүднээс тэднийг няцаах хүртэлх янз бүрийн үзэл бодол гарч ирэв.Сүүлийн үед энэ чиг хандлага хүчээ авч, алагчлахгүй үзэх хандлага улам бага болж байна.«Зогсонги» үеийн нийтлэл ч ховор үзэгдэл болжээ.Энэ нь цаг үеийн хувьдТүвдийн тухай суртал нэвтрүүлгийг ялангуяа хилийн чанадад хүчтэй болгохоор БНХАУ-д шийдвэрлэсэнтэй давхцаж байгаа юм.Тусгайлан сонгож авсан Хятадын түвдчүүд болон Түвд судлаачдын элдэв төрлийн аялал, гадаадын сэтгүүлчдийн Түвдэд хийлгэх аялал, Үзэсгэлэн, нийтлэл, Интернет-сайт зэргийг зохион байгуулж байна.Хятадын эрх баригчдын байр суурийг ул үндэстэй болгох зорилготой баримт сэлтийг нийтлэх болж, харин энэхүҮ байр суурьт харшилсан баримт бичгүүдийн талаар таг дуугүй суух болов” хэмээн бичжээ.Эндээс түвдийн асуудлаарх Оросын байр суурийг харж болохоор байна. Түүнээс гадна түвдийн талаар олон улсад гарч буй мэдээллийг Хятадын эрх баригчид болон түвдийн цагаач иргэд бараг 50 жилийн турш англи, орос зэрэг гадаад хэлээр хийж буйг дурьдаад “хоёр талын гаргаж ирж буй мэдээллүүдийн аль нь үнэн зөв болохыг тэр болгон шалган тогтоож болохгүй байгааг”онцлон тэмдэглэжээ.

Түвдийн асуудал нь улс төрийн асуудалтай холбогддог тул зохиогч эл номоо гадны санхүүгийн дэмжлэггүйгээр зөвхөн хувийн санаачилгаар бичсэн болохоо ч өмнөх үгэндээ дурьдсан байна.

Эхний бүлгүүдэд Цастын өндөр уулс бүхий Түвд орны байгаль, цаг уур, хүмүүсийн аж амьдрал, түүхэн уламжлалын талаар нилээд дэлгэрэнгүй өгүүлсэн бол үүний зэрэгцээ түвд, монголчууд бие биедээ хэрхэн харилцан нөлөөлж байсан учир холбогдлын талаар бичиж, түвд лам нар ямар их эрх мэдэлтэй байсныг ч харуулсан байна. Монголчуудын дунд бурхны шашин дэлгэрч, Монголчууд Түвд нэртэй болсноос одоо хүртэл монголжсон түвд нэр цэвэр монгол нэрнээс бараг цөөнгүй хэмээн тэмдэглэжээ. Мөн долоохоногийн өдөр гаригийн нэр, зарим тооны нэр, уламжлалт цаг тооны бичигзэргийн нэрийг түвд хэлнээс Монголчууд авсныг ч мөн тэмдэглэсэн байна. Нөгөө талаар олон монгол үг, тухайлбал ноёдын цол хэргэм,албан тушаалтай холбоотой үгнүүд түвд хэлэнд нэвтэрч орсныг мөн дурьдсан байна.

Ерөөсөө эл номонд түвд,Монголчуудын харилцааны түүхийн асуудал нилээд хэмжээгээр тусгагдсан тул Монголын түүх, бурханы шашны түүх судлаач хэн бүхэнд хэрэгтэй мэдээлэл олон байгааг тэмдэглэх нь зүй буй за. Тухайлбал, 1904 онд Монголд XIII Далай лам ирсний учир шалтгаан, Оросын талын баримталж байсан бодлого, Далай лам II Николай хааны төлөөлөгчидтэй хэлэлцээ хийж байсан талаар нилээд сонирхолтой зүйлс оржээ.

1911 онд Манж гүрэн задарч, улмаар Түвд тусгаар тогтнолоо зарласнаас 1951 он хүртэлх үеийн Түвдийн засгийн газар, Далай ламын үйл ажиллагаа, учирч байсан саад бэрхшээлийн 
талаар дэлгэрэнгүй өгүүлж, Хятадаас үүнд нь хэрхэн хандаж байсныг тодорхой гаргаж тавьжээ.

1949 оны аравдугаар сарын 1-нд Бээжин хотноо БНХАУ-ыг тунхагласнаас хойш эх газрын хятадад ХКН дангаар засаглал тогтсоосон хэмээн зохиогч бичээд эл үеэс “Түвдрүү хандсан түүний өнгөлзлөг амьдралд хэрэгжих болов” хэмээн дүгнэжээ.

Зохиогч 1951 онд хятад улс түвдийг булаан эзэлснийг “чөлөөлөлт” хэмээн нэрлэдэг, чухамдаа бол хятад түвдийг эзлэн түрэмгийлсэн хэмээн олон баримтаар нотолсон байна. Түүнээс гадна Түвдийн тусгаар тогтнолыг сэргээхийн төлөө хийсэн түвдийн ард олны бослого, тэмцэл, түүнийг нухчин дарсан Хятадын коммунистуудын үйл ажиллагааны талаар маш дэлгэрэнгүй материалд түшиглэж өгүүлсэн байна. Үүнээс болж, 1959 оны гуравдугаар сарын 17-ны шөнө Далай лам, түүний эх, эрэгтэй дүҮ, охин дүҮ, багш нар, дөрвөн сайд, түшмэд болон бие хамгаалагчид Лхасаас нууцаар гарч, Энэтхэг рүҮ дүрвэн одсон талаар тодорхой өгүүлжээ. Түвдийн засгийн газрыг татан буулгасан тухай БНХАУын Төрийн зөвлөл зарласны маргааш өдөр Энэтхэгт очоод байсан Далай лам Түвдийн засгийн эрхбарих хууль ёсны дээд байгууллагыг дахин бий болгожээ. Улмаар 1964 оны Арван хоёрдугаар сард Банчин лам, Далай лам нарыг Бүх Хятадын ардын Төлөөлөгчдийн Хурлын орлогч даргын албан тушаалаас огцруулж,Банчин ламын ойрын хамтран зүтгэгч гурван хүнийг “Банчингийн бүлэгт”оролцогчид хэмээн зарлаж, түүний хөрөнгийг хурааж, Далай ламыг “урвагч”хэмээн зарлаж, Банчин ламыг Бээжинд бусдаас тусгаарласан тухай тэмдэглээд эл үеэс хойшхи БНХАУ болон XIV Далай ламын хоорондын асуудал ямар саад бэрхшээл туулж байгаа талаар тодорхой бичсэн байна. Зохиогч Түвдчүүдийн тусгаар тогтнол, уламжлал, шашнаа хамгаалахын төлөө хийсэн тэмцлийн үр дүнд хэдэн мянган хүн амь үрэгдэж, үгүй болж, хичээн түүх соёлын өв устгагдсан талаар дэлгэрэнгүй өгүүлсэн байна. Мөн соёлын хувьсгал ганц түвдийг биш, БНХАУ-ыг бүхэлд нь хамарч, дэлхийн аугаа их соёлуудын нэг болох хан үндэстний соёлд ч нөхөж баршгүй хохирол учирсныг онцлон тэмдэглэжээ. Тухайлбал, зохиогч бичихдээ “Аугаа их шүтээнүүд, бичгийн дурсгалууд, урлаг, уран барилгын мөнхийн шилдэг бүтээлүүд устгагдаж, гарамгай сэтгэгчид, зураач,зохиолч, жүжигчид,эрдэмтэн мэргэд, Хятадын эртний уламжлалыг тээгчид, бүх төрлийн шашны төлөөлөгчид эрүү шүүлт, доромжлол, шахалт хавчилтад өртөж,олон хүн амь үрэгджээ.Бээжин хотод Соёлын хувьсгалын үеэр 6843 түүхийн дурсгалаас 4922 нь эвдэрч сүйджээ. Энэ хугацаанд түүхийн дурсгалт 2 сая 357 мянганном судар, 185 мянган зураг, хичээнгүй бичгийн хуйлаас устгаж, эртний бичээс бүхий нэг мянга гаруй чулуун багана эвдлэн нураажээ. Тэд мөн аугаа их Хятадын Цагаан Хэрмийн зарим хэсгийг эвджээ” гэх зэргээр бичсэн байна. Гэвч эл бүхний бурууг хятадын ард түмэнд тохох ёсгүй, үүний гол буруутан бол Мао болон хятадын коммунист нам хэмээн дүгнэжээ.

Уг бүтээл орчин үеийн Түвдийн асуудалд маш их анхаарал хандуулсан нь ажиглагдаж байна. Түвдийн түүхийн талаарх сурвалж, үндэслэл дутмаг гарчээ гэж үзэхээр байна. Мэдээж түүхийн асуудал тусдаа сэдэв байж болох ч уг номын оршилд түүхэн үндэслэлийг гаргасан хэмээн хэлсэн нь хангалттай болж чадаагүй мэт.Түүнээс гадна Түвд, Монголыг 
харьцуулах зорилгоор Монголын түүхийн зарим асуудал уг бүтээл дотор хөндөгдөж байгаа нь байраа олоогүй мэт санагдсаныг нуух юун.

Монголд бурхан шашин Түвдээр дамжин дэлгэрч, Монголчууд ихэнхдээ түвд хэлээр бурхны шашинг судалж, ойлгохыг хичээж байдаг ч Түвдийн талаарх ойлголт Монголд хангалтгүй байдгийг бодвол эл ном түвд судлаач, сонирхогч хэн бүхэнд өгөөжтэй байх нь дамжиггүй хэмээн санамой. 